\title{
The Dilemmas of Flexibilisation of Vocational Education and Training: A Case Study of the Piano Makers
}

\author{
Carmen Baumeler, Sonja Engelage, Alexandra Strebel \\ Swiss Federal Institute for Vocational Education and Training, Kirchlindachstrasse 79, \\ 3052 Zollikofen, Switzerland
}

Received: 24 February 2020, Accepted: 27 October 2020

\begin{abstract}
Context: Dual VET systems are often praised for their labour market proximity because of economic stakeholders' involvement. However, when labour market requirements change rapidly, a lack of flexibility is attributed to them. This occurs in times of fast socio-technological change like the current digital transformation. A repeatedly proposed measure to increase system flexibility is to reduce the number of occupations and create broader occupational profiles, for example, by combining similar occupations into so-called occupational fields. However, little is known about actually establishing occupational fields.

Approach: Against this backdrop, we address the following research question: How was an occupational field created? As Switzerland attempted to merge occupations over a decade ago, we selected an information-rich and illuminative case concerning the research question: The piano makers' occupation as one of the first occupations required to merge into an occupational field called musical instrument makers together with organ builders and wind instrument makers. Based on a qualitative case study, we reconstruct the process of occupational field construction by combining expert interviews with comprehensive document analysis and present its narrative.
\end{abstract}

Findings: Based on this case study, we contribute to the understanding of VET flexibilisation by detailing occupational field creation and identifying opportunities and challenges.

*Corresponding author: carmen.baumeler@ehb.swiss 
Here, we pay special attention to the institutional work of the affected occupational association and identify the importance of preserving its collective occupational identity. Although regulatory changes disrupted the piano makers' occupation, the occupational association reinstitutionalised it as part of the musical instrument makers' occupational field. Over a decade later, the piano makers reintroduced their former occupational title, which is deeply connected to their occupational identity.

Conclusion: The results indicate that VET reforms that promote flexibilisation by creating occupational fields encounter serious limitations in collectively governed dual VET systems. In the Swiss system, occupational associations are core collective actors that rely on their members' voluntary work. To maintain these economic stakeholders' necessary commitment to VET, their collective occupational identity, symbolized by their long-standing occupational title, needs to be preserved.

Keywords: Vocational Education and Training, VET, Flexibilisation, Occupational Association, Occupational Field, Institutional Work, Occupational Identity

\section{Introduction}

In collective skill formation systems such as those found in Germany, Austria, and Switzerland, companies, intermediary organisations, and the state work together to provide vocational education and training (VET) (Busemeyer \& Trampusch, 2012). To ensure VET is closely linked to labour market needs, state actors delegate important tasks such as the definition of occupational profiles to intermediary associations (employers' or occupational associations and trade unions), who assume an important role in administering, maintaining, and reforming these systems. These systems are also referred to as dual VET systems, because training occurs not only at school but also in companies, mostly in the form of dual apprenticeships (Gessler, 2017).

Further, dual VET systems are characterised by the occupational principle (Berufsprinzip), which is a social identification and allocation instrument that ensures a close relationship between certified occupational qualifications and employment activities (Severing, 2014; Hellwig, 2008). Occupations impart a wide range of skills that go beyond a single firm's needs (Clarke, 2011; Clarke et al., 2013). This contrasts with, for example, liberal skill formation systems such as the United States, in which VET is not collectively organised and comparatively narrow on-the-job training aimed at immediate workplace requirements prevails.

The close connection to the labour market via integrating economic stakeholders is often seen as a strength of dual VET systems. Yet, when labour market requirements change rapidly, a lack of flexibility has recurrently been attributed to these systems. This is so, for example, during fast socio-technological change like the current digital transformation. A 
repeatedly proposed measure to increase system flexibility is to reduce the number of occupations: For example, by defining core occupations or combining related training occupations into so-called occupational families or occupational fields. This should broaden occupational profiles to improve individual mobility in the labour market and increase training efficiency (Maurer \& Pieneck, 2013; Seufert, 2018).

In Switzerland, the flexibilisation of dual VET was attempted in the early 2000s (Häfeli \& Gasche, 2002). This allows us to examine an implemented process of flexibilisation in retrospect. As part of a major VET reform, the state administration wanted to reduce the number of occupations and to combine similar occupations into occupational fields and train them together. As the occupational associations in Switzerland are responsible for defining the occupational training content, this provoked substantial institutional work on their part. Institutional work is the purposive action of individual and collective actors aimed at creating, maintaining, or disrupting institutions (Lawrence \& Suddaby, 2006). The institutional work perspective states that institutions-or, in our case, occupations-do not only need to be purposefully and actively created and maintained, but their disruption and possible reinstitutionalisation also requires extensive work.

Against this backdrop, we address the following research question: How was an occupational field created? We investigate the case of the piano makers' occupation, which had to merge with organ builders and wind instrument makers into the occupational field of musical instrument makers, as an example of flexibilisation. The long-established traditional handicraft could not uphold the legitimacy of its individual apprenticeship and lost its distinct occupational title in the merging process.

Based on this in-depth case study, we contribute to the understanding of flexibilisation and occupational fields. We detail the process of occupational field construction and identify opportunities and challenges. Here, we pay special attention to the institutional work of the affected occupational association. A key finding is the importance of preserving its collective occupational identity symbolised by its long-standing occupational title.

\section{Conceptual Framework}

\subsection{Occupations and Collective Occupational Identities}

Institutions are enduring elements of social life that provide templates for action, cognition, and emotion (Lawrence et al., 2011). An occupation (Beruf) can be conceived of as being an institution (Lawrence, 2004; Bechky, 2011). It is defined as "a formally recognized social category, with regulative structure concerning VET, qualifications, promotion and the range of knowledge, both practical and theoretical, that is required to undertake the activities that fall 
within it" (Clarke, 2011, p. 103). It represents a division of labour, also referring to particular wage relations, social position, and social status. Apprenticeships define the educational pathways that lead to occupations.

In collective skill formation systems, occupations are based on collective governance where consensus-oriented and time-consuming decision-making involves key sectoral stakeholders (Clarke et al., 2013). Particularly, intermediary organisations such as employer organisations and labour unions occupy a pivotal role in collective governance. Employer organisations are composed of firms or individual professionals and bring knowledge of the skills required by the current economy into the negotiation of training content. Moreover, they provide a platform for their members to exchange information and create shared understandings and normative expectations (Schmitter \& Streeck, 1999). Thus, occupations are social constructs resulting from negotiation processes, rather than mere representations of activities found in the labour market (Dehnbostel, 2005; Schwarz \& Bretschneider, 2014). It is not only legal regulations but also norms, values, and cultural-cognitive elements that underpin them (Nicklich \& Fortwengel, 2017).

More particularly, occupations provide collective occupational identities. Identity, in general, can be understood as "a multi-dimensional classification or mapping of the human world and our places in it, as individuals and as members of collectivities" (Jenkins, 2008, p. 5). Occupational identity answers the question of who we are by way of what we do (Ashcraft, 2013). Occupations might be thought of as having collective selves and are distinguished by collective identities. The definition of occupational competences implies constructing an occupational image and shaping the respective professionals' individual identities: "The occupational identity project (what is it that we do?) merges with occupational image (what do we want them to think that we do?) and often entails a corresponding overhaul of individual practitioner identity (who am I?)" (Ashcraft, 2013, p. 14). Individuals are influenced by a vocational habitus, which is informed by the respective vocational culture (Colley et al., 2003). Consequently, individuals might also develop pride in their occupational affiliation.

\subsection{Flexibilisation of Dual VET}

In the last century, economic and technological development has led to an increasing number of specialised occupations as a result of the differentiation and specialisation of work (Pahl, 2001). The increasing diversity of occupational profiles has repeatedly been a topic of VET policy (Maurer \& Pieneck, 2013). While employers are customarily interested in VET that is closely tailored to their needs and allows apprentices to work productively as quickly as possible, narrow occupational profiles can restrict individual mobility in the labour market. Further, it is argued that constant technological change requires broader competencies. In addition, a high number of occupations in dual VET systems raise costs for the public sector, 
as occupation-specific offers at VET schools are mostly publicly financed. The discussions, therefore, revolve around how narrowly or broadly occupational profiles should be designed.

In the past, the social construct of "occupation" was repeatedly questioned (Wahle \& Walter, 2013). As a result of labour market changes over the last forty years, the erosion of the occupational concept was discussed. In the 1970s and '80s, flexibility was increased due to the further mechanisation of the labour market and the pluralisation of employment careers. In the 1990s, however, transformed in-company work organisation came into force, which created a demand for broader vocational qualifications. Recent debates about individualised employability were also seen as a departure from occupations as collective structural patterns of the employment system. Nevertheless, the occupational construct proved to be resistant and viable (Weiss, 2014).

Recently, demands for greater flexibility in VET have once more become popular (Seufert, 2018). It is argued that in the age of digital transformation, occupations change at high speed, new occupations emerge, and existing ones die. More recent discussions relate the flexibilisation of dual VET to reducing the number of training occupations by, for example, grouping related occupations into core occupations, structuring occupations into occupational families or occupational groups, or to a (moderate to strong) modularisation of vocational training (Brötz et al., 2008; Euler \& Severing, 2006; Hess \& Spöttl, 2008; Pilz, 2005; Seufert, 2018).

Constructing an occupational field is one attempt to raise flexibility and reduce complexity. An occupational field unites occupations with certain similarities concerning activity, training path, and requirements (Häfeli \& Gasche, 2002). In occupational fields, the training of different occupations can be combined, but there also remains specialised content to account for the peculiarities of individual occupations (Schwarz \& Bretschneider, 2014). Constructing occupational fields should provide apprentices with broad skills, improve workers' mobility within the field, and increase training and regulation efficiency. It should also improve transparency by reducing the amount of information for young people who are about to choose an occupation (Häfeli \& Gasche, 2002). Further, there is discussion as to whether the merging of related occupations into occupational fields calls for a new type of didactics in VET schools (Barabasch \& Baumeler, 2019).

\subsection{Institutional Work and Disruption}

As, in collective skill formation systems, occupations are negotiated by employer associations, trade unions, and public authorities (Severing, 2014), collective actors perform institutional work on their occupations. Therefore, flexibilisation measures of VET cannot be implemented by the state without the concerned actors' actual work. 
The institutional work perspective (Lawrence \& Suddaby, 2006; Lawrence et al., 2009, 2011, 2013) deals with various forms of institutional change and focuses on the role of actors in these processes. It states that institutions need to be purposefully and actively created, maintained, and disrupted, and highlights the knowledgeable, creative, and practical work of individuals and collective actors attempting to shape institutions. Institutional work involves reflexive awareness and effort and addresses cultural-cognitive, normative, and regulative institutional pillars (Scott, 2008). This theoretical perspective is especially interested in studying institutional work that is "nearly invisible and often mundane, as in the day-to-day adjustments, adaptations and compromises of actors" (Lawrence et al., 2009, p. 1).

The dissolution of a long-standing occupation is an institutional disruption process. Lawrence and Suddaby (2006) base their concept of institutional disruption work on Oliver's (1992) seminal contribution about deinstitutionalisation. She describes it as a "process by which the legitimacy of an established or institutionalized organizational practice erodes or discontinues" (Oliver, 1992, p. 564). From her perspective, organisations fail to continually reproduce previously taken-for-granted actions. This might be the case when changes in the political field, in laws and societal values, or functional economic considerations call into question the legitimacy of a traditional practice. When the organisational environment changes, deinstitutionalisation can be a pro-active and conscious response from organisations. If they have little influence on these changes, deinstitutionalisation can also be a passive or even unconscious reaction.

Building on Oliver's contribution, Lawrence and Suddaby (2006) identified practices that actors use to disrupt institutions purposively, for example, disconnecting a practice from associated sanctions or rewards. With VET reform, such institutional disruption work occurs if the state questions certain occupations' legitimacy by redefining and re-regulating the process and requirements for designing occupational profiles.

However, it is also possible to disrupt existing institutions by developing new ones (Lawrence \& Suddaby, 2006). Deinstitutionalisation might foster institutional replacement (Oliver, 1992) or "repair work", which is maintenance work carried out to undo disruption (Micelotta \& Washington, 2013). Institutional replacement can also be achieved through reinstitutionalisation. Outsider-driven deinstitutionalisation, such as regulatory change, might destabilise established practices (Maguire \& Hardy, 2009; Greenwood et al., 2002). Organisations may react by innovating and seeking solutions. These innovations need to be justified to gain broader acceptance and legitimacy. New ideas and practices are only fully reinstitutionalised when they become taken-for-granted as a natural and appropriate arrangement, embedded and routinised, which allows their reproduction over time. 


\section{The Swiss Context: VET Reform and Creating Occupational Fields}

In the Swiss collective skill formation system, federal and regional authorities, the cantons, as well as intermediary associations of labour market stakeholders are involved in VET governance. Federal authorities are responsible for strategically developing the VET system and enacting the training ordinances, which are drafted by occupational associations. The 26 cantons organise and finance vocational schools, supervise host companies and offer career counselling. In addition to training in firms and VET schools, inter-company courses provide training in industry-specific occupational skills.

Intermediary associations are the main actors concerned with defining occupational training content. This task is delegated to them based on the assumption that they know best what the labour market needs and can ensure continuous VET adaption. Earlier research identified three types of prominent associations in Switzerland, occupational associations, which represent small firms and self-employed professionals, especially in the crafts and domestic sector of the economy; company associations, which unite a sector's firms; and employee associations (Höpflinger, 1984). Contrary to other countries, intermediary associations in Swiss VET are typically organised along occupational (not sectoral) lines: Currently, 146 associations are responsible for at least one of the approximatively 240 initial VET occupations (Emmenegger et al., 2019; Jenkins, 2008). Occupational associations are, therefore, important educational actors that shape the Swiss VET system (Strebel et al., 2019; Baumeler et al., 2018).

Yet, a major vocational training reform in 2004 increased the role of the federal administration regarding content definition: The administration introduced a standardised procedure that all occupations had to follow by updating training content according to the newly introduced training standards (Berner, 2013). One objective of this process was to reduce the number of occupations. The demand for reducing the existing 300 occupations emerged as a result of criticism of Swiss VET as being too inert, overregulated, and inflexible. This would impede its adaption to rapid employment changes. In this context, it was expected that merging occupations would bring economic, educational, and regulatory benefits. It would lead to broader basic training and less specialisation and, thereby, increase individuals' employability and mobility on the labour market (Bundesrat, 2000). It was also argued that higher numbers of apprentices per occupation and year would result in increased efficiency in training, for example, in vocational schools. The public administration assumed that because of the smaller number of training regulations, there would be less documentation and administrative work. This orientation was also informed by educational research (Häfeli \& Gasche, 2002). At the centre of the discussion were the 130 small occupations with fewer than 100 apprenticeships per year. Hence, the federal administration urged smaller occupational associations to find synergies with similar occupations and carry out parts of VET together. This led to the disruption of various occupations and the creation of new occupational fields. 


\section{Method: Qualitative Case Study}

We explore our research question by conducting a qualitative case study because we want to identify how a flexibilisation measure - an occupational field - was actually created. Qualitative case studies provide a methodological approach that is especially suitable to answer this question (Merriam, 2009; Patton, 2015). The aim of case study research is to conduct in-depth analysis, focussing on the participants' perspective (Harrison et al., 2017). It intends to provide a comprehensive account that helps in understanding the phenomenon. Further, qualitative approaches are suitable for the reconstruction of processes (Langley et al., 2013), and involve questions such as how institutions, or occupations, emerge, develop, or terminate over time.

We used purposeful sampling (Patton, 2015) to select a case that is information-rich and illuminative concerning the research question: The piano makers' occupation, which was one of the first occupations that needed to merge into an occupational field after the 2004 VET reform. In studying this case, we develop an in-depth understanding of the implementation of a flexibilisation measure.

Typically, case studies use various data sources (Harrison et al., 2017). First, we analysed official documents concerning VET reform to set the ground for our empirical study. Second, we conducted semi-structured expert interviews (Bogner et al., 2009; Gläser \& Laudel, 2010) (see table 1) lasting between 47 and 127 minutes with a key representative of the occupational association and two educational consultants who advised the occupational reform process. The interview partners were selected for the following reasons: The key representative of the occupational association was their managing director and the driving force behind the establishment of the occupational field. One educational consultant was active at the time when the occupational field was founded and the other one at a later stage, at which the former occupational titles were regained. We regarded them as experts because of their specialised knowledge of the occupational reform process, which allowed us to reconstruct it.

We used an openly constructed interview guideline that encouraged interviewees to share their experiences and their interpretations of the reform process. As we asked retrospective questions about concrete activities in the disruption of the occupation, the creation of the occupational field and the regaining of the former occupational title, we can reconstruct the process according to their point of view from 2004 until today. We analysed the interviews with regard to their perspective of key events in the process.

Although interviewees can provide information for detailing and interpreting activities over time, they also have their shortcomings (for example, forgetfulness or inaccurate detail recollection, Roulston \& Myungweon, 2018). Therefore, we triangulated our data with a comprehensive document analysis (between-method triangulation, [Flick, 2018]). We included documents about the disruption of the piano makers' occupation and the subsequent creation of the occupational field called "musical instrument makers" from 1949 until today. 
Data sources were official communications (the magazines of the occupational association, website, newspaper articles, government documents, and statistical information), as well as documents that are not publicly available (minutes of meetings) (see table 1).

Table 1: Overview of the Various Data Sources

\begin{tabular}{|c|c|}
\hline Expert Interviews & Archival Data \\
\hline $\begin{array}{l}1\left(127^{\prime}\right) \text {, key representative of the occupational association } \\
\text { during the reform process } \\
1\left(49^{\prime}\right) \text {, educational advisor of the reform process (early } \\
\text { stage) } \\
1\left(47^{\prime}\right) \text {, educational advisor of the reform process (later } \\
\text { stage) }\end{array}$ & $\begin{array}{l}44 \text { Magazines of the occupational association (2009-2020), } \\
28 \text { government documents (ordinances, education plans, } \\
\text { federal council decisions 1949-2019), } \\
23 \text { minutes of meetings of the musical instrument makers' } \\
\text { Commission for Occupational Development \& Quality } \\
(2010-2018) \text {, } \\
13 \text { newspaper articles, } \\
2 \text { statistical databases, } \\
\text { website of the occupational association musical instrument } \\
\text { makers }\end{array}$ \\
\hline
\end{tabular}

In total, we analysed 111 archival data. To characterise the broader context, data from two statistical databases were used to determine the number of piano makers' apprentices since 1965. The newspaper articles provided background information on the occupation and daily work of piano makers and the international developments in the piano market.

To determine the chronology of the process, the analysis of the 28 official government documents including ordinances, education plans and federal council decisions from 1949 to 2019, allowed the identification of the time course and the outcomes of the piano makers' institutional work. Further, the analysis of the occupational association's website allowed the identification of its self-presentation and statutes. Since 2009, the occupational association has published its own magazine aimed at its member companies. Here, it was possible to find more information about the main topics of the construction of the occupational field, the opening of the VET school and the reasons for the re-implementation of the former occupational titles. Furthermore, by accessing the minutes of the musical instrument makers' Commission for Occupational Development and Quality from 2010-2018, we were able to identify further information on decisions regarding adjustments to its apprenticeship.

In combining the different longitudinal data sources, we were able to reconstruct the process of occupational field construction. While the interview data made it possible to identify the perspectives and explanations of key actors, we used the archival documents to identify the context, chronology, outcomes and main topics of the process.

First, we ordered our data chronologically and identified three main stages of the reform process (disruption of the piano makers' occupation, reinstitutionalisation within the 
occupational field, regaining their former occupational title). Second, we connected the different phases with the interviewees' interpretations. For each phase, we identified the major themes that were important for the process, for example how it was decided which occupations should merge to an occupational field, what kind of institutional work was needed to implement the occupational field and which processes and discussions led to the regaining of the former occupational titles. As we used a qualitative research design, it also allowed us to identify themes that emerged from the data, such as the importance of preserving the collective occupational identity. The data was collected and analysed while abiding by ethical research guidelines, such as informed consent and the preservation of anonymity (Schweizerische Gesellschaft für Soziologie, 2007).

\section{$5 \quad$ Results}

Piano making and tuning have always been a niche occupation with low numbers of apprentices. The association of the piano makers, founded in 1947, brings together around 240 piano makers and tuners from all Swiss language regions. It defines the content of vocational training, arranges expertise, and organises events and further training. Management of the association comprises mostly owners of small businesses who work on a voluntary basis.

Yet, while in the 20th century a piano still belonged in every good room, in the 1960s the Swiss had to compete with imports from the Far East. Simultaneously, modern residential construction meant larger pianos hardly found any room. Today, ten times more digital than acoustic pianos are imported into Switzerland and musical instrument makers specialising in the piano are mainly concerned with maintaining, repairing, and tuning these instruments (Grossrieder, 2018).

\subsection{Disruption of the Piano Makers' Occupation}

During the VET reform, the federal administration identified piano makers as one of the small occupations that should be merged into an occupational field. They informed the piano makers and tuners' association that their occupation could no longer exist if it was not integrated into an occupational field with other small craft occupations in the woodworking sector. This started the outsider-driven deinstitutionalisation process and provoked substantial institutional work of the piano makers association.

Fearing their occupation would lose its recognition, the association first discussed possibly abandoning their apprenticeship or stopping training in Switzerland and sending apprentices to a German training centre. However, they rejected the latter idea with the argument that training in Germany lasted only three years instead of four and thus would not offer the same 
training quality. Moreover, this training was not offered in French and, therefore, Frenchspeaking Swiss would be left behind.

Hence, the association decided to participate in the meetings organised by the public administration to determine whether merging with other wood occupations would be possible. These first meetings revealed large differences in the individual occupational activities of the present occupations. However, the occupations that built and maintained musical instruments showed more commonalities than other woodworking occupations. As the key representative of the piano makers remembers:

So, we were the smallest occupations in the craft "working with wood". (...) We were perhaps eight or ten occupations - and (the state administration) arbitrarily made this division and put it in front of us. You are in this pot. And then, there was the phase of anger and indignation. That was predicted to us in advance. Then, (...) the other occupations said, but you have 270 members. The organ builders' association is also relatively large. And the wind instrument makers are also bigger. They all only deal with music. And we're supposed to have a common occupation? And we should learn how to tune? That's nonsense. There was a lot of debate and there was the separation. Then we said, well, then we'll found the occupational association of the musical instrument makers.

Consequently, as one of the first small occupations, the piano makers joined forces with the wind instrument makers and the organ builders to create the occupational field of the musical instrument makers, which implied founding a new umbrella occupational association. The three occupational associations, the federal administration, and the cantons agreed to this solution. Thus, they became pioneers in establishing an occupational field, which also meant that piano makers started reinstitutionalising their apprenticeship within a larger framework.

However, merging came at a high price for piano makers. The federal administration did not allow them to keep their long-standing occupational title. Instead, from then on, they were called "musical instrument makers with a specialisation in piano making and tuning". For the key representative of the piano makers, it was difficult and painful to communicate this loss of identity to members of the association:

We are piano makers! We are not musical instrument makers! We didn't feel at home there. But we had to swallow this toad. We on the board swallowed this toad at some point and said: Okay, if there's no other way, then that's the way it is, then we'll bite the bullet. But then, we suddenly had to stand there and present it to our people as if we were deeply convinced of the whole story. That, of course, caused us trouble. That wasn't a funny situation at all. 


\subsection{Reinstitutionalisation Within an Occupational Field}

Creating an occupational field involved merging three different occupational associations with their respective apprenticeships, which required significant institutional work. The first challenge was identifying common educational content for the different apprenticeships and determining the areas in which occupation-specific education was required. Moreover, all educational plans were to be elaborated in accordance with the new paradigm of competence orientation, introduced in the early 2000s. The public administration supported the occupational reforms financially, which allowed for developing new educational plans and teaching materials. An educational advisor was commissioned to provide support and the process was initiated in accordance with the legal requirements. As the key representative of the piano makers' association remembers:

One of the most difficult tasks was to draw up the education ordinance and plan. We had to be competence-oriented. We knew we had to glue, drill, mill, saw, regulate (...). And we had to define the competences. We didn't know that. (...) We had to do this integration of the different occupations. We had to determine which competencies we could teach at the beginning and where it began to separate. It's like a pyramid that we have a wide stick at the beginning. We all work with wood. We all have musical history. So at the beginning, we could put all apprentices into one class and then with the years of the apprenticeship, it separated more and more. We proceeded exactly according to this scheme. That was one of the most difficult and demanding activities.

A reform commission, including representatives of the federal administration and the cantons, the presidents and examination experts of the associations, as well as some teachers and the Swiss trade association, was formed. They held detailed discussions on merging the occupations because of the novelty of the procedure.

Further, the musical instrument makers had to find a location for their new vocational school and training centre. Only the thirteenth attempt was successful. Whereas several cantons rejected an application, one canton saw the musical instrument makers' request as an opportunity to revive a semi-vacant agricultural vocational school. To equip the school with training material and a new workshop, the occupational association of the piano makers convinced private sponsors who donated a considerable amount of money.

Implementing occupational reform reached the limits of the voluntary system. As the key representative of the piano makers' association states:

It has always gone sharp to the maximum pain threshold. So the hours we needed are simply God's wages. Everyone knew that he was doing it for his occupation. That it was like a matter of honour that you just do that. That one likes to do that. So, in the sense. But we could never hire people at the wage they actually needed. Never. 
It became clear that professional management of the musical instrument makers' umbrella organisation was indispensable because the organisation's members, who had previously worked voluntarily, were no longer able to cope with the additional workload and the loss of income while doing institutional work. As one educational advisor explains:

The piano makers are mostly sole proprietors. Few are employed in larger companies (...). If someone (...) worked for the association, then nothing happened in his business and he would earn no money.

This meant that paid staff had to be hired. However, the associations' membership fees were insufficient to finance the administration of the umbrella association. Because the VET Act newly permitted establishing a mandatory VET fund to which all companies must contribute, regardless of whether they train apprentices or not, the occupational association decided to set up such a scheme to raise additional funds. This led to some contestations and, finally, a person who did not want to pay was sued. As the key representative of the piano makers' occupational association remembers:

There was also someone who wanted to take it to the extreme and said: I certainly won't pay anything! I don't have any employees and I don't repair anything! Then someone he didn't know brought him a trumpet and he said: Of course I can fix it! There we had the proof! Then he went to court and then came the moment of truth. Does the system work? We were anxious about this moment, because we thought if the court said no, then the whole thing would collapse like a house of cards. But the court said that's right what you did. It's quite clear, he has to pay.

In addition, the association argued that importers of musical instruments also benefitted from the good education in Switzerland. Because they had an interest in skilled workers able to maintain the instruments, the association got a levy from these firms.

Finally, the musical instrument makers' apprenticeship with five specialisations (wind instrument making, wind instrument repair, piano making, organ building, organ pipe building) came into force in 2008. Since then, the training consists of a basic study course, organised with other instrument makers, and specific learning content concerning piano making and tuning. On average, 12 apprentices per year start the musical instrument makers' apprenticeship nationwide. During their training, apprentices build an acoustic piano and thus gain in-depth knowledge of the structure and interaction of the instrument's individual parts. The lessons in the training centre are held bilingually and the learning material is available in German and French. 


\subsection{Regaining Their Former Occupational Title}

The new VET Act stipulates that all training occupations must be reviewed and adapted at regular intervals. In 2014, a review of the apprenticeship "musical instrument maker" was carried out. Questionnaires for evaluating the apprenticeship were sent to workplace trainers, VET teachers, and examiners as well as to apprentices. The results were pleasing and the apprenticeship was rated as good to very good. Around $50 \%$ of the apprentices stayed with their companies after completing their training. However, it was criticised that still no common occupational identity as musical instrument makers had developed.

The association of the musical instrument makers decided to revise their apprenticeship and set up a new training ordinance. The most important aim was to regain their former occupational titles. Therefore, all competencies had to be newly described and approved separately for each occupation within the occupational field. The VET content did not change much and cooperation between the individual occupations continued. However, they were no longer called "musical instrument makers". Since 2020, the individual occupations have again a diploma on which their former occupational title (for example, piano maker) is written. As the key representative of the piano makers' association explains:

Therefore, it's just-we then have our family name again. That's the most important thing that changes that way. There are several other things that change, but that was for the piano builder family and the organ builder family such a flaw. This flaw is now being abolished.

Finally, from the point of view of an educational advisor, it was possible to find synergies in cross-occupational competences (e.g., customer consulting, music history) and then train them at a common school location. However, having created an occupational field did not allow musical instrument makers more labour market flexibility because the occupational competences remained too specific, even if partially trained together:

The public administration wants, (...) that there are synergies and that people become more mobile. But an organ builder is completely different from a piano builder. Sorry, you can't use an organ builder as a piano builder in a rush, and you won't be able to do that in the future either.

Thus, in the case of the musical instrument makers, creating an occupational field only reached one of the intended aims of the policy reform by increasing training efficiency, but there was no higher labour market mobility for trained workers. 


\section{Discussion and Conclusion}

Dual VET systems are often praised for their proximity to the labour market because of economic stakeholders' involvement. Nevertheless, they are criticised for being too complex and slow in times of a rapidly changing world of work. The differentiation into many specialised occupations is regarded as being inert, regulation-intensive, and inflexible. One repeatedly proposed solution is to reduce the number of occupations. This is supposed to increase training efficiency and workers' mobility.

The case of the piano makers shows how a regulatory reform delegitimised the existence of a long-standing handicraft occupation. Although the implementation of the flexibilisation measure was influenced by pedagogical concepts, it was carried out top-down by an administrative logic. The piano makers, therefore, needed to merge with other occupations into an occupational field. Yet, the occupation did not just disappear. Rather the piano makers' association developed institutional work to reinstitutionalise their occupation.

Once the small occupations of the piano makers, wind instrument makers and organ builders were disrupted by public administrations' request to merge, their occupational associations started developing innovative solutions. First, they established a new umbrella association and identified synergies in the training content of the individual occupations. This resulted in developing a new training ordinance. In addition, they had to establish the training infrastructure for common vocational schooling. The new training ordinance required purchasing equipment and producing bilingual teaching materials to train all Swiss apprentices together in one location. In addition, VET schoolteachers and workplace trainers had to attend further training. This preparatory work was needed for creating new training routines and embedding the musical instrument makers' apprenticeship in the existing educational landscape. Yet, creating training regulations and establishing the new infrastructure demanded too much voluntary work. This led to professionalisation of the new umbrella association for which paid staff was hired. Moreover, to finance the equipment and staff, the occupational associations needed to raise additional resources.

Importantly, the federal administration initially obliged them to abandon their traditional occupational title of piano makers in favour of the new occupational field title "musical instrument makers". However, the association members' occupational identity and pride fuelled their commitment and motivated them to work for their association voluntarily. Our case study suggests their occupational title is so important to their identity that the piano makers were ready to face additional administrative workload to re-introduce it over ten years following the creation of the occupational field. With this step, they completed their reinstitutionalisation work that finally resulted in establishing a new form of training together with other occupations that, nevertheless, leads to the traditional occupational titles.

In sum, the case study of occupational field creation revealed the following opportunities and challenges: Synergies in the area of vocational schooling, which increased efficiency, 
were achieved. Yet, from the perspective of the association, this increased efficiency of VET schooling was initially outweighed by the workload and need for additional financial resources for establishing the new training ordinance and infrastructure. Moreover, the attempt to create a new collective occupational identity for musical instrument makers failed and training in this occupational field does not seem to allow for greater occupational mobility.

What can we learn from this single case study about the broader topic of flexibilisation of VET? How can the findings of the case study be transferred to other situations in different contexts (in the sense of transferability as a qualitative approach to generalization [Maxwell \& Chmiel, 2014; Schreier, 2018])? As with every qualitative research, the presented case study is highly contextualised.

Switzerland's collective skill formation system relies heavily on the involvement of occupational associations to which central tasks are delegated (e.g., the definition of vocational curricula, responsibility for providing apprenticeships). Thus, implementing reforms to flexibilise VET requires cooperating with these associations, which may develop institutional work to resist change, maintain their position, or reinstitutionalise their occupations. Policy measures informed by educational-conceptual considerations may reach limits when the motivations of the executing actors are not considered. To reduce complexity and the number of occupations, public authorities are confronted with the specific needs of a large number of, mainly small, occupational associations. Importantly, many of these occupational associations rely on members carrying out voluntary work. Our findings suggest that members' voluntary engagement is fostered by connection to their occupational identity and pride. If their occupational identity is not preserved, occupational associations may engage in institutional work to reinstitutionalise it or, if they fail to do so, they might no longer be committed to offering apprenticeships and their members might lose their willingness to train. Consequently, if flexibilisation measures, such as the creation of occupational fields, threaten occupational identities, this may drive the system away from its voluntary character towards a system that is based on more professional, paid work-which may ultimately increase training costs.

In conclusion, the flexibilisation measure of creating an occupational field at least partially calls into question the occupational principle that underpins dual VET systems. Thus, such a policy measure cannot be implemented without considering the governance structure of the respective VET system. Occupational titles that reflect the collective identity of occupational associations respect the crucial role of these intermediary organisations. Therefore, this case study indicates that policymakers may need to strike a balance between searching for training synergies and respecting occupational identities.

Our study points out that a reconstruction of the implementation process of other occupational fields could yield important insights for future flexibilisation measures. It highlights aspects that should first be assessed together with the affected occupations when initiating 
the implementation of new occupational fields. Where are actual benefits to be expected? What level of work and costs does such a reform trigger? Are apprentices also employable in related occupations after training in an occupational field? The consequences of not respecting or consulting occupational experts may be that the measures taken are not sufficiently labour market-oriented, and that implementation fails due to a lack of commitment on the part of those concerned. For the associations of small occupations whose existence may be threatened, this means that they must recognise important pillars of their occupational identity at an early stage and protect them accordingly, vis-à-vis the authorities. In times of reform and change, it is important that the associations involve their members in these processes to secure their commitment. Finally, it is important to emphasise that there is also something to be gained: The creation of occupational fields can certainly lead to positive experiences and synergy with other, similar occupations, and trigger a surge of professionalisation. However, as only little is known about the actual implementation of flexibilisation measures in dual VET, further research is needed to identify opportunities and challenges within the different contexts of other dual VET systems.

\section{References}

Ashcraft, K. L. (2013). The glass slipper: "Incorporating" occupational identity in management studies. Academy of Management Review, 38(1), pp. 6-31. https://www.jstor.org/stable/23416300

Barabasch, A., \& Baumeler, C. (2019). Berufsfelddidaktik in der Schweiz: Internationale Einbettung, Ausdifferenzierung und konkrete Umsetzung [Professional field didactics in Switzerland: International embedding, differentiation and concrete implementation].bwp@ Berufs-und Wirtschaftspädagogik - online, 1-5. https://www.bwpat.de/ausgabe/spezial16

Baumeler, C., Engelage, S., \& Strebel, A. (2018). Creation, maintenance, and disruption. Occupational associations and their heterogeneous institutional work after the Swiss VET policy reform. In C. Nägele \& B. E. Stalder (Eds.), Trends in Vocational Education and Training Research. Proceedings of the European Conference on Educational Research (ECER). Vocational Education and Training Network (pp. 61-69). VETNET. https://eera-ecer.de/ecer-programmes/conference/23/contribution $/ 44171 /$

Bechky, B. A. (2011). Making organizational theory work: Institutions, occupations, and negotiated orders. Organization Science, 22(5), 1157-1167. https://doi.org/10.1287/orsc.1100.0603

Berner, E. (2013). "Verbundpartnerschaft" - Schlagwort oder Erfolgsrezept? [Collective skill formation system - Keyword or recipe for success?]. In M. Maurer \& P. Gonon (Eds.), Herausforderungen für die Berufsbildung in der Schweiz (pp. 37-60). HEP.

Bogner, A., Littig, B., \& Menz, W. (2009). Interviewing Experts. Palgrave Macmillan. https://doi. org/10.1057/9780230244276

Brötz, R., Schapfel-Kaiser, F., \& Schwarz, H. (2008). Berufsfamilien als Beitrag zur Stärkung des Berufsprinzips [Occupational families as a contribution to strengthening the occupational principle]. BWP Berufsbildung in Wissenschaft und Praxis, 4, 23-25. https://www.bibb.de/veroeffentlichungen/de/publication/download/id/1368 
Bundesrat. (2000). Botschaft zu einem neuen Bundesgesetz über die Berufsbildung. [Bulletin on a new federal law on vocational education and training]. Bundesblatt, 5686-5774. https://www.admin.ch/ opc/de/federal-gazette/2000/index_47.html

Busemeyer, M., \& Trampusch, C. (2012). Introduction: The comparative political economy of collective skill formation. In M. Busemeyer \& M. C. Trampusch (Eds.), The Political Economy of Collective Skill Formation (pp. 3-40). Oxford University Press. https://dx.doi.org/10.1093/acprof:o so/9780199599431.003.0001

Clarke, L. (2011). Trade? Job? Or occupation? The development of occupational labour markets for bricklaying and lorry driving. In M. Brockmann, L. Clarke \& C. Winch (Eds.), Knowledge, skills and competence in the European labour market: What's in a vocational qualification? (pp. 102-19). Routledge. https://westminsterresearch.westminster.ac.uk/item/8zx91/trade-job-or-occupationthe-development-of-occupational-labour-markets-for-bricklaying-and-lorry-driving

Clarke, L., Winch, C., \& Brockmann, M. (2013). Trade-based skills versus occupational capacity: The example of bricklaying in Europe. Work, Employment and Society, 27(6), 932-951. https://doi. org/10.1177/0950017013481639

Colley, H., James, D., Diment, K., \& Tedder, M. (2003). Learning as becoming in vocational education and training: Class, gender and the role of vocational habitus. Journal of Vocational Education and Training, 55(4), 471-498. https://doi.org/10.1080/13636820300200240

Dehnbostel, P. (2005). Zum Verhältnis von Arbeiten und Lernen in der betrieblichen Ausbildung [On the relationship between work and learning in company-based training]. In H. Loebe, E. Severing (Eds.), Prozessorientierung in der Ausbildung (pp. 7-20). Bertelsmann Verlag.

Emmenegger, P., Graf, L., \& Strebel, A. (2019). Social versus liberal collective skill formation systems? A comparative-historical analysis of the role of trade unions in German and Swiss VET. European Journal of Industrial Relations, 26(3), 263-278. https://doi.org/10.1177/0959680119844426

Euler, D., \& Severing, E. (2006). Flexible Ausbildungswege in der Berufsbildung [Flexible training paths in vocational education and training]. Forschungsinstitut Berufliche Bildung (f-bb). https://www.fbb.de/fileadmin/user_upload/Studie_Flexible_Ausbildungswege_in_der_Berufsbildung.pdf

Flick, U. (2018). Triangulation in data collection. In U. Flick (Ed.), The SAGE Handbook of Qualitative Data Collection (pp. 527-544). Sage. https://doi.org/10.4135/9781526416070.n34

Gessler, M. (2017). The lack of collaboration between companies and schools in the German dual apprenticeship system: Historical background and recent data. International Journal for Research in Vocational Education and Training, 4(2), 164-195. https://doi.org/10.13152/IJRVET.4.2.4

Gläser, J., \& Laudel, G. (2010). Experteninterviews und qualitative Inhaltsanalyse als Instrumente rekonstruierender Untersuchungen [Expert interviews and qualitative content analysis as instruments of reconstructive research]. VS Verlag. https://cds.cern.ch/record/1336155/files/9783531172385_ TOC.pdf

Greenwood, R., Suddaby, R., \& Hinings, C. R. (2002). Theorizing change: The role of professional associations in the transformation of institutionalized fields. Academy of Management Journal, 45(1), 58-80. https://www.jstor.org/stable/3069285

Grossrieder, B. (2018, January 21). Besuch bei den letzten Klavierstimmern [Visit to the last piano tuners]. Neue Zürcher Zeitung. https://www.nzz.ch/gesellschaft/zu-besuch-bei-den-letzten-klavierstimmern-ld.1348460? reduced=true 
Häfeli, K., \& Gasche, M. (2002). Beruf und Berufsfeld: Konzeptionelle Überlegungen zu kontroversen Begriffen [Occupation and occupational field: Conceptual considerations on controversial terms]. BBT. https://edudoc.educa.ch/static/infopartner/sammlung_fs/2002/SIBP/sibp_Berufsfelder.pdf

Harrison, H., Birks, M., Franklin, R., \& Mills, J. (2017). Case study research: Foundations and methodological orientations. Forum qualitative Sozialforschung/ Forum Qualitative Social Research, 18(1). https://nbn-resolving.de/urn:nbn:de:0114-fqs1701195

Hellwig, S. (2008). Zur Vereinbarkeit von Competency-Based Training (CBT) und Berufsprinzip - Konzepte der Berufsbildung im Vergleich [On the compatibility of Competency-Based Training (CBT) and occupational principle - concepts of vocational education and training in comparison]. Springer VS. https://doi.org/10.1007/978-3-531-90981-3

Hess, E., \& Spöttl, G. (2008). Kernberufe als Baustein einer europäischen Berufsbildung [Core occupations as a component of European vocational education and training]. BWP Berufsbildung in Wissenschaft und Praxis, 37(4), 27-30.

Höpflinger, F. (1984). Verbände [Associations]. In U. Klöti (Ed.), Handbuch politisches System der Schweiz (pp. 163-188). Haupt.

Jenkins, R. (2008). Social Identity. Routledge. https://doi.org/10.4324/9780203463352

Langley, A., Smallman, C., Tsoukas, H., \& Van de Ven, A. (2013). Process studies of change in organization and management: Unveiling temporality, activity, and flow. Academy of Management Journal, 56(1), 1-13. https://www.jstor.org/stable/23414342

Lawrence, T. B. (2004). Rituals and resistance: Membership dynamics in professional fields. Human Relations, 57(2), 115-143. https://doi.org/10.1177/0018726704042924

Lawrence, T. B., Leca, B., \& Zilber, T. B. (2013). Institutional work: Current research, new directions and overlooked issues. Organization Studies, 34(8), 1023-1033. https://doi. org/10.1177/0170840613495305

Lawrence, T. B., Suddaby, R., \& Leca, B. (2011). Institutional work: Refocusing institutional studies of organization. Journal of Management Inquiry, 20(1), 52-58. https://doi. org/10.1177/1056492610387222

Lawrence, T. B., Suddaby, R., \& Leca, B. (2009). Institutional work: Actors and agency in institutional studies of organizations. Cambridge University Press. https://doi.org/10.2189/asqu.2010.55.4.673

Lawrence, T. B., \& Suddaby, R. (2006). Institutions and institutional work. In S. R. Clegg, C. Hardy, T. B. Lawrence \& W. R. Nord (Eds.), The SAGE Handbook of Organization Studies (pp. 215-254). Sage. https://www.academia.edu/6776718/Institutions_and_institutional_work

Maguire, S., \& Hardy, C. (2009). Discourse and deinstitutionalization. The decline of DDT. Academy of Management Journal, 52(1), 148-78. https://www.jstor.org/stable/40390280

Maurer, M., \& Pieneck, S. (2013). Die Reform von Berufsbildern als ständige Auseinandersetzung über Form und Inhalt [The reform of occupational profiles as an ongoing debate about form and content]. In M. Maurer \& P. Gonon (Eds.), Herausforderungen für die Berufsbildung in der Schweiz (pp. 81-100). HEP. https://www.hep-verlag.ch/media/import/preview/herausforderungenfuerdieberufsbildung.pdf

Maxwell, J. A., \& Chmiel, M. (2014). Generalization in and from qualitative analysis. In U. Flick (Ed.), The SAGE Handbook of Qualitative Data Analysis (pp. 540-553). Sage. https://doi. org/10.4135/9781446282243.n37

Merriam, S. B. (2009). Qualitative research. A guide to design and implementation. Revised and expanded from qualitative research and case study applications in education. Wiley \& Sons. 
Micelotta, E. R., \& Washington, M. (2013). Institutions and maintenance: The repair work of Italian professions. Organization Studies, 34(8), 1137-1170. https://doi.org/10.1177/0170840613492075

Nicklich, M., \& Fortwengel, J. (2017). Explaining the puzzling stagnation of apprenticeships in Germany's security services: A case of insufficient institutional work? Journal of Professions and Organization, 4(3), 302-323. https://www.researchgate.net/publication/318987480_Explaining_ the_puzzling_stagnation_of_apprenticeships_in_Germany\%27s_security_services_A_case_of_ insufficient_institutional_work

Oliver, C. (1992). The antecedents of deinstitutionalization. Organization Studies, 13(4), 563-588. https://doi.org/10.1177/017084069201300403

Pahl, J.-P. (2001). Berufsfelder - Basis fachwissenschaftliche und didaktischer Reflexionen beruflichen Lernens [Occupational fields - Basis of scientific and didactic reflections on vocational learning]. In K. Häfeli, M. Wild-Näf \& T. Elsässer (Eds.), Berufsfelddidaktik. Zwischen Fachsystematik und Handlungsorientierung (pp. 17-37). Schneider Verlag.

Patton, M. Q. (2015). Qualitative research \& evaluation methods: Integrating theory and practice. Sage. Pilz, M. (2005). Modularisierung in der Beruflichen Bildung. Ansätze, Erfahrungen und Konsequenzen im europäischen Kontext [Modularisation in vocational education and training. Approaches, experiences and consequences in the European context]. Schweizerische Zeitschrift für Bildungsforschung, 27(2), 207-230. https://docplayer.org/163783070-Matthias-pilz-hg-modularisierungsansaetze-in-der-berufsbildung-deutschland-oesterreich-schweiz-sowie-grossbritannien-im-vergleich.html

Roulston, K., \& Myungweon, C. (2018). Qualitative interviews. In U. Flick (Ed.), The SAGE Handbook of Qualitative Data Collection (pp. 233-249). Sage. https://doi.org/10.1177/1468794117721738

Schmitter, P. C., \& Streeck, W. (1999). The organization of business interest. MPIfG Discussion Paper, 99(1). Max-Planck-Institut für Gesellschaftsforschung. https://pure.mpg.de/pubman/faces/ViewItemFullPage.jsp?itemId=item_1235421_1

Schreier, M. (2018). Sampling and generalization. In U. Flick (Ed.), The SAGE Handbook of Qualitative Data Collection (pp. 84-98). Sage. http://dx.doi.org/10.4135/9781526416070.n6

Schwarz, H., \& Bretschneider, M. (2014). Strukturmodelle als Ansatz zur Flexibilisierung anerkannter Ausbildungsberufe im dualen System [Structural models as an approach to making recognised training occupations in the dual system more flexible]. In E. Severing \& R. Wei $($ Eds.), Weiterentwicklung von Berufen - Herausforderungen für die Berufsbildungsforschung (pp. 181-197). Bertelsmann Verlag. https://www.agbfn.de/dokumente/pdf/agbfn_14_schwarz_bretschneider.pdf

Schweizerische Gesellschaft für Soziologie. (2007). Ethik in der soziologischen Praxis [Ethics in sociological practice]. Bulletin, 132. Seismo. https://www.sgs-sss.ch/wp-content/uploads/2016/03/ Bulletin_132.pdf

Scott, W. R. (2008). Institutions and organizations. Ideas and interests. Sage. https://digitalcommons. usu.edu/unf_research/55/

Seufert, S. (2018). Flexibilisierung der Berufsbildung im Kontext fortschreitender Digitalisierung [Flexibilisation of vocational education and training in the context of progressive digitisation]. SBFI. https://www.sbfi.admin.ch/sbfi/de/home/dienstleistungen/publikationen/publikationsdatenbank/ berufsbildung-digitalisierung.html

Severing, E. (2014). Weiterentwicklung von Berufen - Herausforderungen für die Berufsbildungsforschung [Development of occupations - Challenges for VET research]. In E. Severing \& R. Wei $\beta$ (Eds.), Weiterentwicklung von Berufen - Herausforderungen für die Berufsbildungsforschung (pp. 
5-10). Bertelsmann Verlag. https://www.pedocs.de/volltexte/2015/10084/pdf/Severing_2014_ Weiterentwicklung_von_Berufen.pdf

Strebel, A., Engelage, S., \& Baumeler, C. (2019). Der Beitrag der "institutional work"-Perspektive zu Educational Governance. Dezentrale institutionelle Arbeit in der Berufsbildung [The contribution of the "institutional work" perspective to educational governance. Decentralised institutional work in VET]. In R. Langer \& T. Brüsemeister (Eds.), Handbuch Educational Governance Theorien (pp. 201-218). Springer VS. https://doi.org/10.1007/978-3-658-22237-6_10

Wahle, M., \& Walter, M. (2013). Beruf, Beruflichkeit, Berufsbildung [Occupation, occupational becoming, vocational education and training].bwp@ Berufs-und Wirtschaftspädagogik - online. https:// www.bwpat.de/ht2013/ws23/wahle_walter_ws23-ht2013.pdf

Weiss, R. (2014). Zwischen wissenschaftlicher Relevanz und politischer Akzeptanz - Die Rolle der Forschung bei der Entwicklung und Strukturierung von Berufen [Between scientific relevance and political acceptance - The role of research in the development and structuring of occupations]. In E. Severing \& E. R. Weiss (Eds.), Weiterentwicklung von Berufen - Herausforderungen für die Berufsbildungsforschung (pp. 11-29). Bertelsmann Verlag. https://doi.org/10.3278/111-061w011

\section{Biographical Notes}

Prof. Dr Carmen Baumeler is head of research and development at the Swiss Federal Institute for Vocational Education and Training. Her research interests focus on educational and organisational sociology with reference to VET.

Dr Sonja Engelage is a senior researcher at the Swiss Federal Institute for Vocational Education and Training. Her research interests focus on educational and occupational careers, gender, and migration, as well as educational governance.

Alexandra Strebel is a junior researcher at the Swiss Federal Institute for Vocational Education and Training. Her research interests focus on VET governance and occupational associations, as well as the institutional change of VET system. 